Review

\title{
History, organization and contents of the Yellow River basin groundwater project
}

\author{
Wen Dongguang ${ }^{1}$ \\ Wen Dongguang (2009) History, organization and contents of the Yellow River basin groundwater \\ project. Bull. Geol. Surv. Japan, vol. 60 (1/2), p. 5-8.
}

Keywords: Yellow River basin, groundwater model, numerical simulation, China Geological Survey (CGS), Geological Survey of Japan (GSJ)

\section{History of the project and its purpose and significance}

The Yellow River is the second largest river of China, and the river basin is the birthplace of Chinese civilization. In the basin, the Hehuang Valley, Yinchuan Plain, Hubao Plain, Ordos Basin, Guanzhong Basin, Taiyuan Basin, etc. are important grain-producing areas as well as energy and chemical industrial bases, showing great potential for economic development. However, the Yellow River basin is situated in arid and semiarid regions of China, where water resources are not sufficient, economic environment is fragile, and droughts and floods occur frequently, all of which greatly constrain the sustainable development of social economy of the basin.

From 1970s to the end of 1990s, drying up of the Yellow River occurred almost every year. The discharge of many tributaries decreased continuously. Groundwater was over-extracted in many cities. The areas where lowering of groundwater level occurs have expanded year after year, and quality of surface and groundwater has deteriorated. All these have seriously constrained the sustainable development of social economy of the basin area.

In accordance with the Memorandum of Understanding between China Geological Survey (CGS) and National Institute of Advanced Industrial Science and Technology (AIST), Japan, the two institutions signed an agreement to jointly work on the project of "Collaboration on Modeling and Future Prediction of Balance, Circulation and Utilization of Groundwater" in March 2003. Through research on the balance, circulation and utilization of groundwater in the Yellow River basin, the project aimed to set up a numerical model of groundwater in the basin, to predict the trend of groundwater changes in the coming 10 to 20 years, so as to provide scientific support for the rational development and utilization of groundwater in the basin.
During the development of the project in China, concern and support were shown by Ms. Shou Jiahua, former Vice Minister of Land and Resources and Mr. Wang Min, Vice Minister of Land and Resources and Director General of China Geological Survey, Mr. Yin Yueping, Director of the Department of Hydrogeology and Environmental Geology, China Geological Survey, Mr. Wu Xuanmin, Deputy Director of the same department, Mr. Shi Jiansheng, Director of the Institute of Hydrogeology and Environmental Geology, Chinese Academy of Geological Sciences. Other experts concerned have offered guidance to the framework of the project often, thereby providing important guarantee for the smooth implementation of the project.

The target of the project was to carry out in-depth research on the changes of frozen soil in the source area of the Yellow River based on a systematic collection of relevant data, and on the groundwater dynamic features, isotope characteristics, and the circulation and balance of groundwater in the Yellow River basin to establish numerical model of groundwater in the basin, and to make prediction of future groundwater changes in the basin.

\section{Organization of the project and participating institutions}

The project was organized by two parties, CGS and Geological Survey of Japan (GSJ) which is a sector of AIST. On Chinese side, the Institute of Hydrogeology and Environmental Geology, Chinese Academy of Geological Sciences and China Institute of Geoenvironment Monitoring were technically responsible with the participating units including Geological Environmental Monitoring Station of Qinghai Province, Geological Environmental Monitoring Station of Gansu Province, Geological Environmental Monitoring Station of Ningxia Hui Autonomous Region, Institute of Geological Environmental Monitoring of Inner Mongolia

${ }^{1}$ China Geological Survey 
Autonomous Region, Geological Environmental Monitoring Station of Shaanxi Province, Geological Environmental Monitoring Center of Shanxi Province, Institute of Geological Environmental Monitoring of Henan Province, and Geological Environmental Monitoring Station of Shandong Province along the Yellow River reaches. In the Japanese side, the participants included were, besides those with GSJ, researchers from the University of Tsukuba, Hokkaido University, Geosphere Environmental Technology Corp. (GETC) and National Institute of Environmental Studies (NIES).

On the Chinese side, Wen Dongguang and Zhang Eryong of the CGS were in charge of the project, and Zhang Fawang and Han Zhantao of the Institute of Hydrogeology and Environmental Geology, Chinese Academy of Geological Sciences, and Gao Cunrong of China Institute of Geoenvironmental Monitoring were responsible for technical affairs. On the Japanese side, Takemasa Ishii of GSJ was in charge. Hirofumi Muraoka, Shiro Tamanyu, Youhei Uchida, Yusaku Taguchi and Minoru Urai of GSJ, Norikazu Matsuoka and Atsushi Ikeda of the University of Tsukuba, Tetsuo Sueyoshi of Hokkaido University (now at the University of Tokyo), Koji Mori, Tetsu Nishioka and Kazuhiro Tada of GETC, and Toshiaki Ichinose and Kuninori Otsubo of NIES were participating in research works of the project.

\section{Contents of the project}

The duration of the project was 5 years from March 2002 to March 2007. During the 5 years, the two sides carried out 12 joint field investigations, and the Chinese side conducted 3 field investigations on its own, with a total of some 110 days for field work. The investigations covered all the major groundwater basins in the Yellow River basin. The main works completed are listed in the following;

1) Continuous monitoring made for 2 years on the groundwater levels in the major plains and basins in the Yellow River reaches using 96 sets of groundwater level automatic monitoring instruments, at a monitoring frequency of once per hour.

2) Ten (10) groundwater sampling profiling in the Yellow River basin, collecting 100 hydrochemical samples and 160 isotope samples, among which 85 hydrochemical samples and 132 isotope samples were from groundwater, and 15 hydrochemical samples and 28 isotope samples from surface water.

3) Typical investigations and monitoring conducted on the changes of frozen soil in the source area of the Yellow River, including 21 shallow drillings, 24 artificial seismic profiles (240 points), 36 apparent resistivity geophysical profiles, 15 monitoring points for surface temperature, and 1 synthetic monitoring point for frozen soil parameters.

4) Interpretation of the amount of groundwater extraction in the whole basin by using the DMSP (Defense Meteorological Satellite Program) remote sensing method.

5) Interpretation of the thickness of Quaternary aquifers in the whole basin taking the SRTM (Shuttle Rader Topography Mission) 30 data from the NASA, USA, as data source.

6) Establishment of a unified groundwater flow model for the basin, and a prediction for the changes in groundwater flow field within the coming 10 to 20 years using the software "GETFLOWS" developed by GETC.

In addition, the two parties held 4 seminars.

\section{Investigation methods and main achievements}

The project was for the prediction of groundwater evolution in the Yellow River basin, and centered on the establishment of a unified groundwater model of the basin through data collection, field investigation, hydrochemical and isotope analyses, groundwater level and frozen soil monitoring as well as remote sensing and interpretation as means of data acquisition using software "GETFLOWS" which was able to make unified modeling of atmospheric water, surface water, soil water and groundwater as the modeling tool, to establish a systematic groundwater flow model of the study area. Using the input and fitting of the precipitation, groundwater level and surface water discharge in the past 20 years, the model was corrected and ultimately provided prediction of the water demand, groundwater level etc. for the coming 10 to 20 years. Our main achievements are as follows;

1) Establishment of three-dimensional geologic structure model based on remote sensing interpretation and correlative analyses of multiple data.

2) Installation of an automatic monitoring network of groundwater in major areas of the Yellow River basin providing long-term groundwater dynamic monitoring data.

3) Further understanding of groundwater circulation features in the basin through groundwater dynamic monitoring and analyses of hydrochemical and isotope data.

4) Preliminary analyses on the causes and rules of frozen soil degradation in the Yellow River source region, as well as the impacts of frozen soil changes on the runoff and ecological environment in the source region through investigation and monitoring of frozen soil in typical source areas.

5) Establishment of a numerical model of groundwater in the basin, and prediction for the future trends incurring from different plans of groundwater 
extraction in the basin.

\section{Remaining problems and work to be done in the Future}

Our five-year project was finished in March, 2007 and we still have some unsolved problems.

1) A numerical model of groundwater in the basin has been established. However, as our data and understanding are still limited, further correction would be needed for the conceptual model of hydrogeology and the parameters, so that the model fits the real conditions better. On these conditions the model can be used for continuous prediction and research of the groundwater changes in the basin in the future.

2) The impacts of frozen soil changes on the runoff and ecological environment in the source areas were studied in the project, but research on the impacts of future climate changes and influence of human activities on the water resources of the basin should be strengthened.

Received December, 15, 2008

Accepted December, 19, 2008 


\section{黄河地下水プロジェクトの経緯, 組織, 成果の概要 \\ ウェンドンガン}

\section{要 旨}

中国と日本との国際共同研究として実施された黄河流域地下水プロジェクトの経緯，組織，5年間の成果概要につい て述べる. 本プロジェクトは, 中国地質調査局と産業技術総合研究所とで結ばれた MOU（研究協力覚書）に基づき実 施されたものである。中日双方は，中国第2の河川である黄河の広大な流域を対象に，地下水と表流水などに関する現 地水文資料の収集, 凍土分布に関するモニタリングと物理探査, 地下水の水質分析や酸素・水素安定同位体分析，水文 地質構造の解析などにより,地下水の収支・循環機構解明に資するデータの取得に努めた.また, これらのデータをフィー ドバックしつつ, 黄河流域の地下水循環モデルを構築して, 同流域の現在と過去 20 年間にわたる地下水頭の再現, シ ナリオに基づく 2020 年まで 5 年毎の地下水状態の予測を行った. 